\title{
Analisa Prediksi Jumlah Pembuatan Roti Menggunakan Penerapan Metode Fuzzy Inference System Dengan Algoritma Tsukamoto
}

\author{
Munawaroh*) \\ Jurusan Teknik Informatika, Universitas Pamulang, Tangerang Selatan \\ Jln. Surya Kencana No. 1, Pamulang - Tangerang Selatan, 15417, Indonesia \\ email: ishmuna.im@gmail.com \\ Received: 23 Maret 2018; Revised: 9 Mei 2018; Accepted: 13 Mei 2018 \\ Copyright @2018 Politeknik Harapan Bersama Tegal. All rights reserved
}

\begin{abstract}
The number of unsold bread causes PT Seru Bakery to suffer a loss. This is based on the absence of a system that regulates the making of bread on PT.Seru Bakery, so that the making of bread refers only to the wishes of the author alone. In PT exciting Bakery there are 2 Size of bread and each - each type consists of 3 flavors. For small bread is priced Rp.1000 and has a taste of chocolate, cheese and coconut, for a large bread that sells for Rp.2000 that is mocha, pia and fried chocolate. This research use method of fuzzy tsukamoto inference system using 3 variable that is, demand, inventory, and production, application of method of fuzzy tsukamoto in making planning to determine amount of production expected to increase profit where maximum production obtained from maximal sale and at least reduce amount the number of returns in the previous few months, if the lowest demand is 661 brown bread/day and highest The highest demand is 922 brown bread / last request problem $=735$ chocolate flavour bread, as well as the lowest supply, is 278 chocolate flavour bread / day, highest supply is 643 chocolate flavour bread/day and Supply problems $=635$ chocolate flavour bread, then the bread produced is as much as 1284 bread, the difference between manual calculation and the system of 86 pieces of bread. So with the FIS method Tsukamoto can suppress losses of 86 pieces of bread.
\end{abstract}

Abstrak - Banyaknya roti yang tidak terjual menjadi penyebab PT Seru Bakeri mengalami kerugian. Hal tersebut didasarkan karena tidak adanya system yang mengatur pembuatan roti pada PT.Seru Bakeri, sehingga pembuatan roti hanya mengacu kepada keinginan si pembuatnya saja. Pada PT seru Bakeri terdapat 2 Ukuran roti dan masing - masing jenis terdiri dari 3 rasa. Untuk roti ukuran kecil diberi harga $R \mathbf{R p . 1 0 0 0}$ dan mempunyai rasa coklat, keju dan kelapa, untuk roti yang berukuran besar yang dijual seharga Rp.2000 yaitu moka, pia dan coklat goreng. Penelitian kali ini menggunakan metode Sistem inferensi fuzzy tsukamoto dengan menggunakan 3 variabel yaitu, permintaan, persediaan, dan produksi, penerapan metode fuzzy tsukamoto dalam membuat perencanaan untuk menentukan jumlah produksi diharapkan dapat meningkatkan keuntungan dimana produksi yang maksimal diperoleh dari penjualan yang maksimal dan

*) Corresponding author: Munawaroh

Email: ishmuna.im@gmail.com setidaknya mengurangi banyaknya jumlah retur pada beberapa bulan sebelumnya, jika Permintaan terendah adalah 661 roti coklat/hari dan tertinggi Permintaan tertinggi adalah 922 roti coklat/hari lalu permintaan permasalahan $=735$ roti coklat, serta persediaan terendah adalah 278 roti coklat/hari, Persediaan tertinggi adalah 643 roti coklat/hari dan Persediaan permasalahan $=635$ roti coklat, maka roti yang diproduksi adalah sebanyak 1284 roti, selisih antara perhitungan manual dan secara system sebesar 86 buah roti. Jadi dengan FIS metode Tsukamoto bisa menekan kerugian sebanyak 86 buah roti.

Kata Kunci - Fuzzy Inference System, Produksi, Optimalisasi, Prediksi Produksi, Tsukamoto, Fuzzy Tuskamoto, Roti.

\section{PENDAHULUAN}

PT Roti "Seru Bakery" yang berada di jalan Serua Raya Raya Gg. Haji Nidi Kota Depok, perusahaan ini bergerak di bidang produksi roti, dimana roti adalah makanan yang sangat banyak dipasaran [1], makanan ini mencangkupi dari masyarakat bawah sampai dengan masyarakat atas, begitu juga dengan makanan ini biasanya disukai dari anak-anak sampai dengan orang dewasa. Roti adalah makanan terbuat dari tepung terigu yang diberi ragi roti dan dipanggang [2]. Adonan roti sendiri bisa diberikan macam - macam rasa, misalnya : Coklat, Strawberry, kopi, dan lain sebagainya [3].

Dalam pembuatan roti dibutuhkan perhitungan yang baik [4] dan pada PT. Roti Seru Bakery ini belum memiliki sistem dalam pengelolaan untuk perhitungan membuat produksi roti, terlepas dari hal tersebut berkembangnya sebuah teknologi didunia perindustrian atau usaha dimana pekerjaan seseorang manusia akan sangat membutuhkan dalam sesuatu pengolahan sebuah data [5], Produksi yang baik adalah produksi yang mempunyai keuntungan maksimal yang dimana didapatkan dari penjualannya yang maksimal [6][7]. Apabila produksi roti jauh lebih banyak dari jumlah permintaan konsumen maka perusahaan akan mengalami kerugian. PT. Roti Seru Bakeri sering kali menderita kerugian karena ketidaktaun dalam menganalisa keinginan konsumen, PT. Seru Bakeri hanya mengandalkan Intuisi bukan berdasarkan fakta serta data dalam memproduksi roti, 
seberapa banyak roti yang dibuat dan rasa apa saja yang akan dibuat dan pembagian presentase rasa pada roti tersebut. Dilihat dari masalah diatas perlu dilakukan Analisa dan dibutuhkan suatu teknologi dalam menentukan keputusan dalam pembuatan roti berapa banyak yang harus diproduksi. Metode yang digunakan oleh penulis adalah dengan mengimplementasikan metode Fuzzy Inference System menggunakan Algoritma Tsukamoto dengan mengambil sampel data yaitu data persediaan dan data permintaan serta data produksi pada PT. Seru Bakeri.

Tujuan dari penelitian ini adalah untuk menentukan nilai jumlah produksi yang baik dalam memenuhi permintaan konsumen yang fluktuatuif, diperlukan suatu alternatif pemecahan masalah tanpa menambah serta memberikan fasilitas yang ada, yaitu dengan mengimplementasikan metode Fuzzy tsukamoto kedalam sistem aplikasi. Penerapan metode Fuzzy Inference System dengan algoritma tsukamoto dalam membuat perencanaan untuk menentukan jumlah produksi diharapkan dapat meningkatkan keuntungan dimana produksi yang maksimal didapatkan dari suatu penjualan yang maksimal.

\section{PENELITIAN YANG TERKAIT}

Dalam penelitian yang dilakukan oleh Baha Guney pada tahun 2016 yang berjudul "Fuzzy Linear Programming Approach For Determining The Production Amounts In Food Industry" [8], membahas tentang menentukan jumlah produksi dalam industri makanan dengan menggunakan pendekatan model Fuzzy Linear Programming, yang menghasilkan sebuah kesimpulan memberikan jumlah produksi untuk setiap jenis produk untuk mendapatkan keuntungan maksimum, yang menggunakan pendekatan algoritma Zimmerman yang merupakan salah satu pendekatan untuk fuzzy linear programming.

Dalam penulisan penelitian ini, peneliti banyak Penelitian yang dilakukan oleh Fathurrahman Kurniawan Ikhsan pada tahun 2014 yang berjudul, "Penerapan Fuzzy Tsukamoto Dalam Sistem Pendukung Keputusan Untuk Menentukan Jumlah Produksi Barang" [9], membahas tentang menentukan produksi barang dengan menggunakan metode Fuzzy Inference System dengan algoritma Tsukamoto dan menghasilkan kesimpulan dengan menerapan metode Fuzzy Tsukamoto sebagai pengambil keputusan dapat menghasilkan banyak kemudahan yaitu dengan menggunakan metode ini kepraktisan dalam menentukan keputusan dan memudahkan dalam menghitung jumlah produksi dengan memasukkan data permintaan, persediaan, dan produksi ke dalam sistem.

Penelitian selanjutnya dilakukan oleh Murni Marbun pada tehun 2016, dengan judul penelitiannya "Perancangan Sistem Perencanaan Jumlah Produksi Roti Menggunakan Metode Fuzzy Mamdani" [10], membahas tentang perancangan suatu sistem perencanaan dalam menentukan jumlah dari produksi roti dengan menggunakan metode Fuzzy Inference System dengan algoritma Mamdani, dan menghasilkan sebuah sistem yang dibangun dengan menggunakan bahasa pemrograman visual basic 6.0. dan untuk databasenya menggunakan microsoft acces 2007, dan mendapat kesimpulan bahwa implementasi Logika fuzzy Mamdani dinyatakan efektif yang diterapkan kedalam sistem aplikasi untuk memberikan bantuan kepada pihak perusahaan Judens Bakery dan dalam menentukan jumlah dari produksi roti ini diambil berdasarkan banyaknya data persediaan dan banyaknya data jumlah permintaan.

Berdasarkan penelitian sebelumnya dimana membahas tentang jumlah produksi dengan menerapkan metode fuzzy inference system hanya saja berbeda dalam menggunakan beberapa algoritma didalamnya, selanjutnya berdasarkan penelitian sebelumnya ini maka peneliti melakukan penelitian dengan membahas masalah yang serupa yaitu tentang menentukan jumlah produksi dengan menerapkan metode fuzzy inference system menggunakan algoritma tsukamoto berdasarkan metode dari penelitian sebelumnya, selanjutnya data yang diambil berdasarkan pengamatan dari banyaknya jumlah permintaan dan dari banyaknya jumlah persediaan untuk menentukan jumlah produksi pada ruang lingkup menentukan jumlah produksi roti.

\section{A. Analisa Kebutuhan}

\section{METODE PENELITIAN}

Dalam metode penelitian ini selanjutnya dilakukan sebuah analisa kebutuhan sistem sesuai dengan kebutuhan data yang diperlukan untuk melakukan prediksi produksi roti dalam mengurangi jumlah persediaan yang menumpuk dengan Fuzzy Inference System (FIS). Kebutuhan sebuah sistem yang dianalisa dibagi menjadi dua, yaitu analisa data dan analisa kebutuhan [11]. Dalam analisa data membahas data apa saja yang akan diperlukan dalam memenuhi kinerja sistem, dan analisa kebutuhan adalah menganalisa sebuah sistem yang terkait apa saja yang akan dibutuhkan oleh sistem [12], untuk dapat melakukan prediksi produksi roti dalam mengurangi jumlah persediaan yang menumpuk dengan fuzzy inference system (FIS) sesuai dengan tujuan yang diharapkan.

TABEL I

ATURAN PRODUKSI FUZZY TSUKAMOTO

\begin{tabular}{|c|c|}
\hline \multicolumn{2}{|c|}{ Proses Produksi Roti Memakai 4 Aturan/rule Fuzzy } \\
\hline \multirow{2}{*}{ R1 } & $\begin{array}{c}\text { IF (Jika) Sebuah Nilai Permintaan Turun And Nilai } \\
\text { Persediaan Banyak }\end{array}$ \\
\cline { 2 - 3 } & THEN (Maka) Nilai Produksi Roti Berkurang \\
\hline \multirow{2}{*}{ R2 } & $\begin{array}{c}\text { IF (Jika ) Sebuah Nilai Permintaan Turun And Nilai } \\
\text { Persediaan Sedikit }\end{array}$ \\
\cline { 2 - 2 } & THEN (Maka) Nilai Produksi Roti Berkurang \\
\hline \multirow{2}{*}{ R3 } & $\begin{array}{c}\text { IF (Jika) Sebuah Nilai Permintaan Naik And Nilai } \\
\text { Persediaan Banyak }\end{array}$ \\
\cline { 2 - 2 } & THEN (Maka) Nilai Produksi Roti Bertambah \\
\hline \multirow{2}{*}{ R4 } & $\begin{array}{c}\text { IF (Jika) Nilai Permintaan Naik And Nilai Persediaan } \\
\text { Sedikit }\end{array}$ \\
\cline { 2 - 2 } & THEN (Maka) Nilai Produksi Roti Bertambah \\
\hline
\end{tabular}

TABEL II

TABEL SAMPLE 1 MingGU

\begin{tabular}{|c|c|c|c|c|c|}
\hline Roti & Status & Tanggal & Permintaan & Persediaan & Produksi \\
\hline \multirow{4}{*}{ Coklat } & \multirow{4}{*}{ Weekday } & $08 / 06 / 15$ & 735 & 635 & 1370 \\
\cline { 3 - 6 } & $09 / 06 / 15$ & 787 & 633 & 1420 \\
\cline { 3 - 6 } & $10 / 06 / 15$ & 868 & 643 & 1511 \\
\cline { 3 - 6 } & $11 / 06 / 15$ & 861 & 459 & 1320 \\
\cline { 3 - 6 } & $12 / 06 / 15$ & 661 & 529 & 1190 \\
\cline { 3 - 6 } & $13 / 06 / 15$ & 922 & 278 & 1200 \\
\hline
\end{tabular}

Metode Tsukamoto untuk prediksi produksi roti dalam mengurangi jumlah retur dengan Fuzzy Inference System (FIS) berdasarkan metode fuzzy Tsukamoto Terdapat 3 variabel fuzzy yang selanjutnya didapatkan aturan dari produksi, dimana dapat dilihat di tabel I. 
yaitu :

- Permintaan: Terdiri 2 himpunan fuzzy, yaitu turun \& naik

- Persediaan: Terdiri 2 himpunan fuzzy, yaitu sedikit \& banyak

- Produksi: Terdiri 2 himpunan fuzzy, yaitu berkurang \& bertambah

Dalam pembuatan produksi roti keseluruhan biasanya mencapai 8.000 roti sampai dengan 20.000 roti untuk weekday perharinya, sementara disaat weekend biasanya produksi roti tersebut membuat produksi roti biasanya mencapai 1.200 roti sampai dengan 8.000 roti per-harinya, yang dapat dilihat berdasarkan tabel II.

Data sample 1 minggu adalah data hasil oleh yang dilakukan selama 1 minggu, dimana data sample 1 minggu yang nantinya data ini akan diuji menggunakan perhitungan aturan metode fuzzy tsukamoto.

a) Tabel Data Sample: Penjualan Produksi Roti Pada PT. Seru Bakery, Pada table II ini akan menggunakan 1 variasi rasa sebagai uji sample 1 minggunya, yang bisa dilihat di Tabel II :

b) Perhitungan Aturan Metode Tsukamoto: Pada tahap ini, dilakukan perhitungan menggunakan aturan metode tsukamoto menggunakan sample penjualan produksi roti selama 1 minggu, pada hari senin.

\section{B. Proses Himpunan Fuzzy}

1) Permintaan

Terdiri dari 2 himpunan fuzzy, yaitu (1) TURUN, dan (2) NAIK dapat dilihat pada gbr. 1.

Diketahui :

Permintaan terendah adalah 661 roti coklat/hari Permintaan tertinggi adalah 922 roti coklat/hari Permintaan permasalahan $=735$ roti coklat

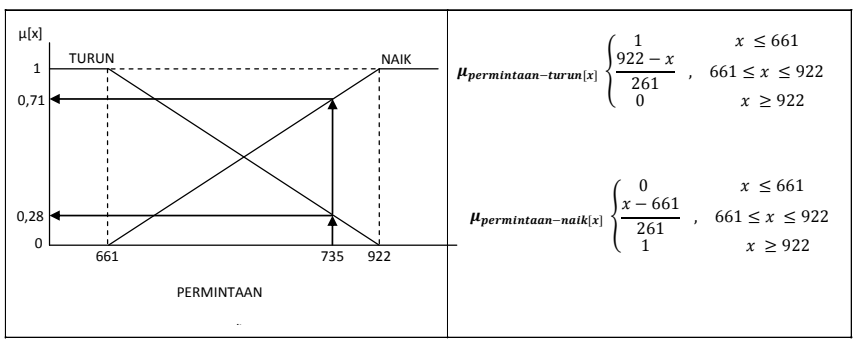

Gbr. 1 himpunan fuzzy, yaitu (1) Turun, dan (2) Naik

2) Persediaan

Terdiri dari 2 himpunan fuzzy, yaitu (1) SEDIKIT, dan (2) BANYAK, dapat dilihat pada gbr. 2.

Diketahui :

Persediaan terendah adalah 278 roti coklat/hari

Persediaan tertinggi adalah 643 roti coklat/hari

Persediaan permasalahan $=635$ roti coklat

\section{3) Produksi}

Terdiri dari 2 himpunan fuzzy, yaitu BERKURANG, dan BERTAMBAH, dapat dilihat pada gbr. 3 .

Diketahui :

Produksi terendah adalah 1190 roti coklat/hari

Produksi tertinggi adalah 1511 roti coklat/hari

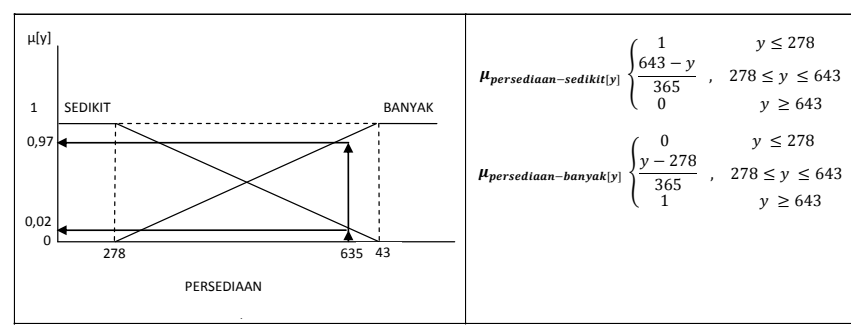

Gbr. 2 himpunan fuzzy, yaitu (1) Sedikit, Dan (2) Banyak

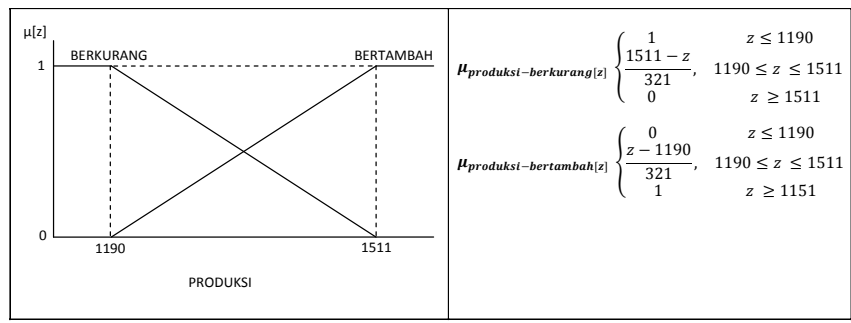

Gbr. 3 himpunan fuzzy, yaitu Berkurang, dan Bertambah

[R1] IF (Jika) Nilai Permintaan TURUN And Nilai Persediaan BANYAK

THEN (Maka) Nilai Produksi Roti BERKURANG

Predikat $1=\mu$ permintaanTURUN $\cap \mu$ persediaanBANYAK

$=\min (\mu$ permintaanTURUN[735], $\mu$ persediaanBANYAK [635])

$=\min (0,71 ; 0,97)$

$=0,71$

Himpunan Produksi Roti Berkurang (1511-z)/321 = 0,71

Hitung $\mathbf{Z 1}=0,71 \times 321=227,91$

$1511-227,91=1.283,09$

Jadi $\mathbf{Z 1}=1.283,09$

[R2] IF (Jika) Nilai Permintaan TURUN And Nilai Persediaan SEDIKIT

THEN (Maka) Nilai Produksi Roti Berkurang

Predikat 2= $\mu$ permintaanTURUN $\cap \mu$ persediaanSEDIKIT

$=\min (\mu$ permintaanTURUN[735], $\mu$ persediaanSEDIKIT[635

$=\min (0,71 ; 0,02)$

$=0,02$

Himpunan Produksi Roti Berkurang (1511-z)/321 = 0,02

Hitung $\mathbf{Z 2}=0,02 \times 321=6,42$

$1511-6,42=1.504,58$

Jadi $\mathbf{Z 2}=1.504,58$

[R3] IF (Jika) Nilai Permintaan NAIK And Nilai Persediaan BANYAK

THEN (Maka) Nilai Produksi Roti Bertambah

Predikat $3=\mu$ permintaanNAIK $\cap \mu$ persediaanBANYAK

$=\min (\mu$ permintaanNAIK [735], $\mu$ persediaanBANYAK [635])

$=\min (0,28 ; 0,97)$

$=0,28$

Himpunan Produksi Roti Bertambah (z-1190)/321 = 0,28

Hitung Z3: 0,28 x $321=89,88$

$89,88+1190=1.279,88$

$\mathbf{Z 3}=1.279,88$

[R4] IF (Jika) Nilai Permintaan NAIK And Nilai Persediaan SEDIKIT

THEN (Maka) NilaiProduksi Roti Bertambah 
Predikat4 $=\mu$ permintaanNAIK $\cap \mu$ persediaanSEDIKIT

$=\min (\mu$ permintaanNAIK[735], $\mu$ persediaanSEDIKIT[635])

$=\min (0,28 ; 0,02)$

$=0,02$

Himpunan Produksi Roti Bertambah (z-1190)/321 = 0,02

Hitung Z4: 0,02 x $321=6,42$

$6,42+1190=1.196,42$

$\mathbf{Z 4}=1.196,42$

Hitung Z sebagai berikut :

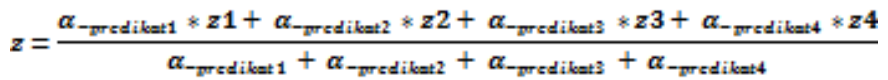

$0,71 \approx 1,283,09+0,02 * 1,504,58+0,28 * 1,279,88+0,02 \approx 1,196,42$ $0,71+0,02+0,28+0,02$

$z=\frac{1,323,38}{1,03}=1.284,83$

TABEL IIII

TABEL PENGUJian ButTon Hitung

\begin{tabular}{|c|c|}
\hline \multicolumn{2}{|r|}{ Kasus Dan Hasil Uji (Data Normal) } \\
\hline Data masukkan & $\begin{array}{l}\text { a. Input Persediaan Max, Persediaan Min, Persediaan } \\
\text { Permasalahan. } \\
\text { b. Input permintaan Max, Pemintaan Min, Permintaan } \\
\text { Permasalahan. } \\
\text { c. Input Produksi Max, Produksi Min }\end{array}$ \\
\hline Yang diharapkan & 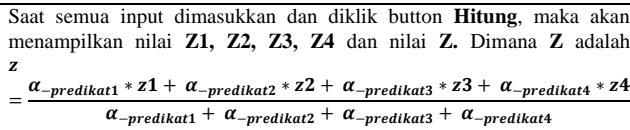 \\
\hline Pengamatan & $\begin{array}{l}\text { Nilai } \mathbf{Z} \text { pada aplikasi setelah diklik button Hitung, nilainya selisih } 2,24 \\
\text { dengan perhitungan manual dimana, nilainya sebagai berikut: } \\
\text { System Aplikasi }=1282,59 \\
\text { Perhitungan Manual }=1.284,83\end{array}$ \\
\hline Kesimpulan & Sukses. \\
\hline
\end{tabular}

\begin{tabular}{|l|l|}
\hline \multicolumn{5}{|c|}{ Kasus Dan Hasil Uji (Data Salah) } \\
\hline Data masukkan & a. Input Persediaan Max, Persediaan Min, Persediaan \\
& Permasalahan. \\
& b. Input permintaan Max, Pemintaan Min, Permintaan \\
& Permasalahan. \\
c. Input Produksi Max, Produksi Min
\end{tabular}

IV. HASIL DAN PEMBAHASAN

Implementasi merupakan keadaan dimana sistem siap untuk digunakan pada keadaan yang sebenarnya, keberhasilan penerapan sistem informasi akan mendukung organisasi dalam proses pencapaian tujuan [13], sehingga akan diketahui apakah sistem yang dibuat telah berfungsi sesuai dengan tujuan yang diinginkan. Sebelum program diterapkan atau diimplementasikan, maka program haruslah melewati fase pengecekan dan pengujian agar terbebas dari segala macam bentuk kesalahan [14]. Dengan tahapan implementasi menggunakan model SDLC dalam rancang bangunnya dan pengujian sistem, maka aplikasi yang dibuat dapat diketahui kualitasnya [15].

\section{A. Pengujian Sistem Blackbox}

Berdasarakan rencana pengujian yang telah disusun, maka dapat dilakukan pengujian sebagai berikut yang dapat dilihat pada Tabel III.

\section{B. Pengujian Kuesioner}

Pengujian kuesioner diambil berdasarkan sampel berupa pertanyaan yang telah dibagikan kepada beberapa sampel seperti pengguna atau seseorang yang menggunakan sistem aplikasi tersebut, koesioner yang dibagikan dibagi berdasarkan katagori penilaian untuk mengukur nilai presentasi dari aplikasi yang sudah dibuat, nilai tersebut adalah nilai efektifitas dan nilai tampilan dari aplikasi, selanjutnya dapat dilihat pada Tabel IV dan Tabel V.

TABEL IV

Tabel Pengujian Nilai PResentase Efektifitas

\begin{tabular}{|c|c|c|c|c|c|c|c|c|}
\hline Katagori & $\begin{array}{c}\text { Sangat } \\
\text { Efektif }\end{array}$ & Efektif & $\begin{array}{c}\text { Cukup } \\
\text { Efektif }\end{array}$ & $\begin{array}{c}\text { Biasa } \\
\text { Saja }\end{array}$ & $\begin{array}{c}\text { Kurang } \\
\text { Efektif }\end{array}$ & $\begin{array}{c}\text { Tidak } \\
\text { Efektif }\end{array}$ & $\begin{array}{c}\text { Sangat } \\
\text { Tidak } \\
\text { Efektif }\end{array}$ & $\begin{array}{c}\text { Jumlah } \\
\text { Pertanyaan }\end{array}$ \\
\hline $\begin{array}{c}\text { Pertanyaan } \\
\text { Ke1 }\end{array}$ & 4 & 5 & 1 & 0 & 0 & 0 & 0 & 10 \\
\hline $\begin{array}{c}\text { Pertanyaan } \\
\text { Ke3 }\end{array}$ & 2 & 6 & 1 & 1 & 0 & 0 & 0 & 10 \\
\hline $\begin{array}{c}\text { Pertanyaan } \\
\text { Ke5 }\end{array}$ & 4 & 4 & 2 & 0 & 0 & 0 & 0 & 10 \\
\hline $\begin{array}{c}\text { Pertanyaan } \\
\text { Ke6 }\end{array}$ & 2 & 3 & 4 & 1 & 0 & 0 & 0 & 10 \\
\hline $\begin{array}{c}\text { Pertanyaan } \\
\text { Ke7 }\end{array}$ & 4 & 2 & 2 & 2 & 0 & 0 & 0 & 10 \\
\hline $\begin{array}{c}\text { Pertanyaan } \\
\text { Ke8 }\end{array}$ & 0 & 2 & 3 & 5 & 0 & 0 & 0 & 10 \\
\hline $\begin{array}{c}\text { Pertanyaan } \\
\text { Ke10 }\end{array}$ & 6 & 4 & 0 & 0 & 0 & 0 & 0 & 10 \\
\hline $\begin{array}{c}\text { ETotalKatagori } \\
\text { Presentasi }\end{array}$ & $31,43 \%$ & $37,14 \%$ & $18,57 \%$ & $12,86 \%$ & $0 \%$ & $0 \%$ & $0 \%$ & $100 \%$ \\
\hline
\end{tabular}

TABEL V

TABEL PENGUJIAN NILAI PRESENTASE TAMPILAN

\begin{tabular}{|c|c|c|c|c|c|c|c|c|}
\hline Katagori & $\begin{array}{c}\text { Sangat } \\
\text { Baik }\end{array}$ & Baik & $\begin{array}{c}\text { Cukup } \\
\text { Baik }\end{array}$ & $\begin{array}{c}\text { Biasa } \\
\text { Saja }\end{array}$ & $\begin{array}{c}\text { Kurang } \\
\text { Baik }\end{array}$ & $\begin{array}{c}\text { Tidak } \\
\text { Baik }\end{array}$ & $\begin{array}{c}\text { Sangat } \\
\text { Tidak } \\
\text { Baik }\end{array}$ & $\begin{array}{c}\text { Jumlah } \\
\text { Pertanyaan }\end{array}$ \\
\hline $\begin{array}{c}\text { Pertenyaan } \\
\text { Ke2 }\end{array}$ & 2 & 7 & 1 & 0 & 0 & 0 & 0 & 10 \\
\hline $\begin{array}{c}\text { Pertenyaan } \\
\text { Ke4 }\end{array}$ & 2 & 3 & 5 & 0 & 0 & 0 & 0 & 10 \\
\hline $\begin{array}{c}\text { Pertenyaan } \\
\text { Ke9 }\end{array}$ & 3 & 3 & 2 & 2 & 0 & 0 & 0 & 10 \\
\hline $\begin{array}{c}\sum \text { TotalKatagori } \\
\text { Presentasi }\end{array}$ & 7 & 13 & 8 & 2 & 0 & 0 & 0 & 30 \\
\hline
\end{tabular}

\section{1) Tampilan Utama}

Tampilan utama menampilkan halaman utama pada aplikasi yang disudah dibuat, dan dapat dilihat pada Gbr. 4. 


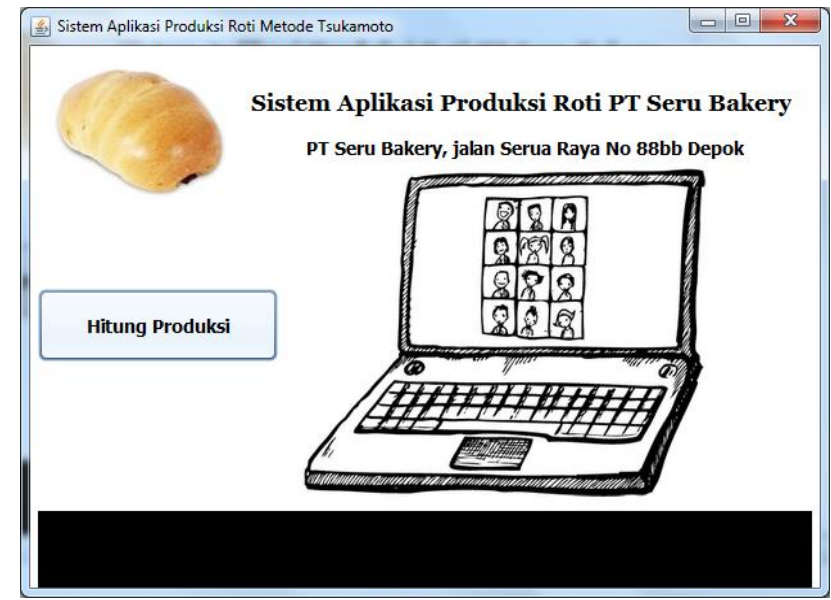

Gbr. 4 Tampilan Halaman Depan Aplikasi Produksi Roti

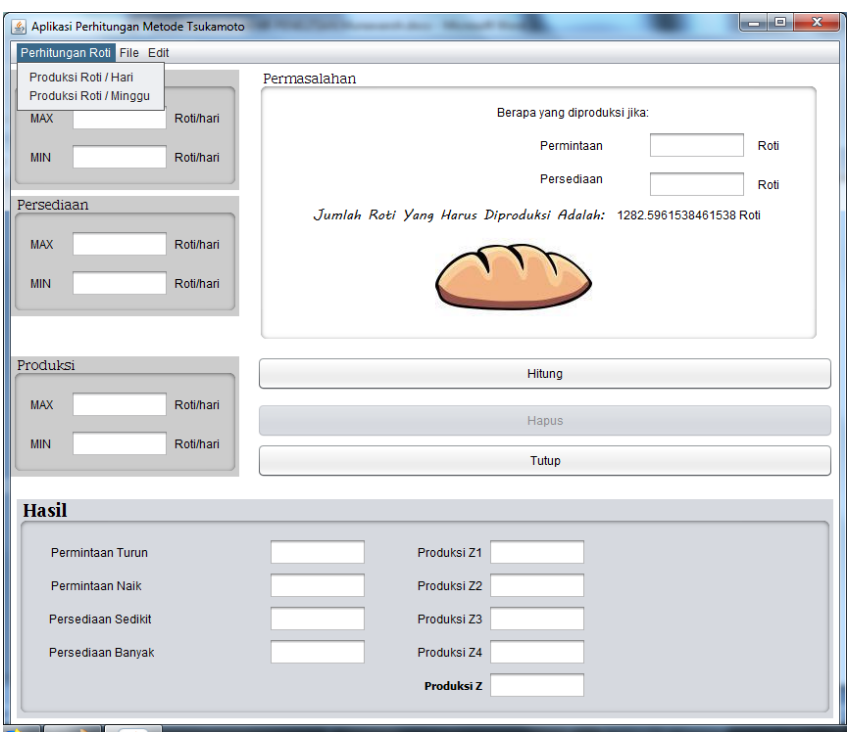

Gbr. 5 Tampilan Halaman Menghitung Jumlah Produksi

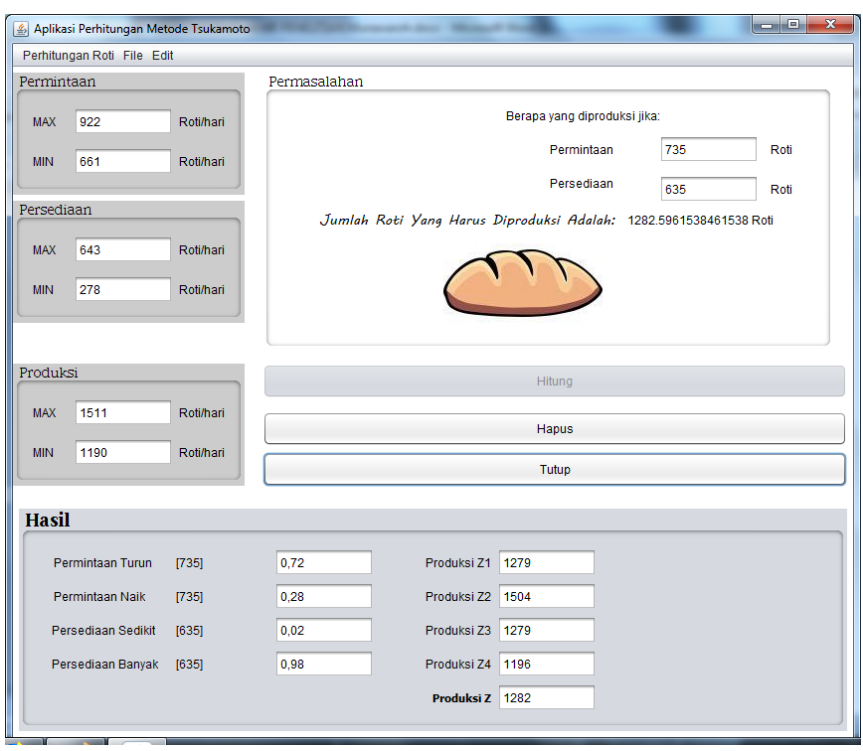

Gbr. 6 Tampilan Halaman Menghitung Jumlah Sample Produksi

\section{2) Tampilan Hitung Produksi}

Menampilkan halaman utama untuk menentukan nilai yang akan diproduksi dengan memasukkan nilai turun, naik permintaan dan nilai sedikit, banyak persediaan dan juga memasukkan nilai data produksi berkurang bertambah selanjutnya memasukkan nilai permasalahan berupa nilai persediaan dan permintaan untuk mendapatkan nilai produksi, yang dapat dilihat pada Gbr. 5.

\section{3) Tampilan Hasil}

Menampilkan hasil dari nilai yang sudah dimasukkan, dan berupa nilai produksi, yang dapat dilihat pada Gbr. 6 .

\section{KESIMPULAN}

Kesimpulan yang diperoleh dari penelitian ini adalah dengan menggunakan system inference fuzzy metode tsukamoto jumlah produksi roti lebih sedikit yaitu sebanyak 1284 buah dibandingkan dengan tanpa menggunakan metode tsukamoto yaitu 1370 dengan menggunakan jumlah persediaan dan permintaan yang sama, dari selisih tersebut bisa diketahui jika dengan menggunakan metode tsukamoto bisa mengurangi kerugian pada PT. Seru Bakeri.

Dan pengujian black box sesuai yang diinginkan, dimana setiap button dan fungsinya sudah berjalan dengan baik dan sudah ditesting, aplikasi ini bisa ditarik kesimpulan aplikasi yang dibangun efektif dalam memperhitungkan jumlah produksi roti, dimana memiliki nilai presentasi efektifitas sebanyak $37,14 \%$, dan $31,43 \%$ menyatakan sangat efektif, yang diambil berdasarkan 7 parameter. aplikasi yang dibangun berbasis dekstop dan memiliki tampilan yang mudah digunakan dengan tidak menggunakan database diprosesnya, dimana nilai presentasi dari pengambilan koesioner dari nilai tampilan adalah $43,33 \%$ menyatakan baik dari tampilan.

\section{UCAPAN TERIMA KASIH}

Ucapan terima kasih ditunjukan kepada PT. Seru bakeri yang telah mengijinkan melakukan penelitian atau riset pada PT tersebut dan semua pihak yang telah terlibat dan membantu dalam penelitian ini.

\section{DAFTAR PUSTAKA}

[1] B. Lenka, P. Petra, M. Lucia, K. Kristína, S. Vojtech, C. Zuzana, and Š. Ernest, "Development of Innovative Health Beneficial Bread using a Fermented Fibre-glucan Product. Food Analysis, Food Quality and Nutrition". Czech J. Food Sci., 33, 2015 (2): 118-125. doi: 10.17221/42/2014-CJFS.

[2] R. Różyło, and L. Janusz, "Predicting Bread Quality (Bread Loaf Volume and Crumb Texture). Food Quality and Functionality".Pol. J. Food Nutr. Sci., 2011, Vol. 61, No. 1, pp. 61-67.

[3] K. M. Sutrisno, Teknologi Pengelolaan Roti. eBookPangan.com, 2, (2009)

[4] Famuwagun. AA, Taiwo. KA, Gbadamosi. SO, and Oyedele. DJ, "Optimization of Production of Bread Enriched With Leafy Vegetable Powder", Journal of Food Processing \& Technology, 2016, 7:7.

[5] S. Beben, "Optimalisasi Aplikasi Transaksi Penjualan Berbasis Web Menggunakan Framework Codeigniter (Studi Kasus: Rumah Makan Tirta Sandi Sumedang)", Jurnal Informatika:Jurnal Pengembangan IT (JPIT), Vol. 2, No. 1, Januari 2017.

[6] L. R. Dorteus, "Penerapan Logika Fuzzy Metode Sugeno Untuk Menentukan Jumlah Produksi Roti Berdasarkan Data Persediaan Dan Jumlah Permintaan (Studi Kasus: Pabrik Roti Sarinda Ambon)," Jurnal Ilmu Matematika dan Terapan. 2015. 
[7] M Enitan. Abimbola, and Adeyemo. Josiah, "Food processing optimization using evolutionary algorithms". African Journal of Biotechnology. Vol.10(72), pp. 16120-16127, 16 November, 2011.

[8] Guney. Baha, Teke. Cagatay, and Tas. Mehmet, "Fuzzy Linear Programming Approach For Determining The Production Amounts In Food Industry", International Journal Of Mechanical And Production Engineering, ISSN: 2320-2092, Volume- 4, Issue-1, Jan.-2016.

[9] K. I. Fathurrahman, "Penerapan Fuzzy Tsukamoto Dalam Sistem Pendukung Keputusan Untuk Menentukan Jumlah Produksi Barang. Lembaga Pengembangan Pembelajaran, Penelitian \& Pengabdian Kepada Masyarakat”, 2014.

[10] Marbun. Murni, T. S. Hengki, V. M. Normi, "Perancangan Sistem Perencanaan Jumlah Produksi Roti Menggunakan Metode Fuzzy Mamdani, "Jurnal Mantik Penusa, Volume 20, No.1, Desember 2016.

[11] Haque. Nurul, "A Brief Study On Needs Analysis. Express", an International Journal of Multi Disciplinary Research. ISSN: 2348 2052 , Vol. 1, Issue 1, January 2014.
[12] Rikalovic. Aleksandar, and Cosic. Ilija, "A Fuzzy Expert System for Industrial Location Factor Analysis”,. Acta Polytechnica Hungarica, Vol. 12, No. 2, 2015.

[13] M. K. Johan, and D. S. Angellia, "Analysis Of Information System Implementation In Binus University Using Delone And Mclean Information System Success Model And Cobit Framework," International Journal of Communication \& Information Technology (CommIT), Vol. 7 No. 1 May 2013, pp. 13-17

[14] S. G. Sukhdev, "Software Testing Techniques", International Journal of Computer Science and Mobile Computing ( IJCSMC), Vol. 3, Issue. 10, October 2014, pp.988 - 993.

[15] Tuteja. Maneela, and Dubey. Gaurav, “A Research Study on importance of Testing and Quality Assurance in Software Development Life Cycle (SDLC) Models,,. International Journal of Soft Computing and Engineering (IJSCE), ISSN: 2231-2307, Volume2, Issue-3, July 2012. 